\title{
WORKERS' COMPENSATION IS ASSOCIATED WITH WORST CLINICAL RESULTS AFTER LUMBAR FUSION
}

\author{
COMPENSAÇÃO TRABALHISTA É ASSOCIADA A PIORES RESULTADOS CLÍNICOS \\ APÓS ARTRODESE LOMBAR \\ COMPENSACIÓN LABORAL ES ASOCIADA CON LOS PEORES RESULTADOS CLÍNICOS \\ DESPUÉS DE ARTRODESIS LUMBAR
}

\author{
Luis Marchi ${ }^{1}$, Joes Nogueira-Neto ${ }^{1}$, Vivian Amaral ${ }^{1}$, Rodrigo Amaral ${ }^{1}$, Nicholal Faulhaber ${ }^{1}$, Etevaldo Coutinho ${ }^{1}$, Leonardo Oliveira', \\ Rubens Jensen ${ }^{1}$, Luiz Pimenta ${ }^{1,2}$ \\ 1. Instituto de Patologia da Coluna (IPC), São Paulo, SP, Brazil. \\ 2. University of California, San Diego (UCSD), California, USA.
}

\begin{abstract}
Objective: The objective of this study was to evaluate the association of clinical results with preoperative situation of worker compensation (WC) in patients submitted to spine surgery. Methods: This was a retrospective, comparative, single center study. Patients who underwent lumbar spine arthrodesis were included. The outcomes were pain scores (VAS), physical constraint (ODI) and quality of life (EQ5D). Outcomes were analyzed before surgery and after surgery (minimum follow-up of six months and maximum of 12). Two groups were compared: individuals with or without WC at preoperative visit. Results: A total of 132 cases were analyzed (mean age 54 years and $51 \%$ female), 29 (22\%) assigned to the WC group. The groups were matched for age, sex, and preoperative depression levels. In the preoperative period, the groups showed equal pain and physical constraint; however the CT group had lower quality of life ( $p=0.05)$. Although both groups showed improvement in clinical outcomes after surgery $(p<0.05)$, worse scores were observed for the WC group compared to the non-WC group, respectively: VAS 4.9 vs. 3.2 ( $p=0.02$ ), ODI 34.7 vs. 23.4 ( $p=0.002$ ), and EQ-5D 0.56 vs. 0.75 ( $p=0.01$ ). Conclusion: In this study it was possible to observe that WC is associated with worse clinical results following elective surgical treatment of the lumbar spine.
\end{abstract}

Keywords: Spine/surgery; Working conditions; Quality of life; Work; Arthrodesis; Spinal fusion; Psychology, social.

\section{RESUMO}

Objetivo: O objetivo deste estudo foi avaliar a associação de resultados clínicos à situação pré-operatória de compensação trabalhista (CT) em pacientes submetidos à cirurgia de coluna. Métodos: Este estudo foi retrospectivo, comparativo e em único centro. Foram incluídos pacientes que passaram por artrodese da coluna lombar. Os desfechos clínicos foram escores de dor (EVA), restrição física (ODI) e qualidade de vida (EQ-5D). Os desfechos foram analisados antes e depois da cirurgia (acompanhamento mínimo de seis meses e máximo de 12). Dois grupos foram comparados: indivíduos sem ou com CT na visita pré-operatória. Resultados: No total foram analisados 132 casos (média de idade 54 anos e 51\% do sexo feminino), sendo 29 (22\%) do grupo com CT. Os grupos se mostraram pareados quanto a idade, sexo e nível de depressão pré-operatória. No pré-operatório os grupos se mostraram iguais quanto a dor e restrição física, porém, o grupo com CT apresentava qualidade de vida inferior $(p=0,05)$. Apesar de os dois grupos terem mostrado melhora nos desfechos clínicos após a cirurgia $(p<0,05)$, observaram-se piores escores para o grupo com CT comparado com grupo sem CT, respectivamente: EVA 4,9 vs. 3,2 ( $p=0,02), O D I 34,7$ vs. 23,4 ( $p=0,002)$ e EQ-5D 0,56 vs. 0,75 ( $p=0,01)$. Conclusão: No presente trabalho, foi possível observar que a CT está ligada a piores resultados clínicos após tratamento cirúrgico eletivo da coluna lombar.

Descritores: Coluna vertebral/cirurgia; Condições de trabalho; Qualidade de vida; Trabalho; Artrodese; Fusão vertebral; Psicologia social.

\section{RESUMEN}

Objetivo: El objetivo de este estudio fue evaluar la asociación de resultados clínicos con la condición preoperatoria de compensación laboral (CL) en pacientes sometidos a cirugía de columna. Métodos: Este estudio fue retrospectivo, comparativo y en un único centro. Se incluyeron pacientes sometidos a la artrodesis de la columna lumbar. Los parámetros clínicos analizados fueron puntuaciones de dolor (EVA), restricción física (ODI) y calidad de vida (EQ-5D). Esos parámetros se analizaron antes y después de la cirugía (seguimiento mínimo de seis meses y máximo de 12). Se compararon dos grupos: pacientes sin o con CL en la visita preoperatoria. Resultados: En total se analizaron 132 casos (promedio de edad 54 años y 51\% del sexo femenino), siendo 29 (22\%) del grupo con CL. Los grupos eran pareados en cuanto a edad, sexo y nivel de depresión preoperatoria. En el preoperatorio los grupos se mostraron iguales en cuanto al dolor y restricción física, pero el grupo con CL presentaba calidad de vida inferior $(p=0,05)$. Aunque los dos grupos hayan mostrado una mejora en los parámetros clínicos después de la cirugía $(p<0,05)$, se obsenvaron puntuaciones más bajas en el grupo de CL en comparación con el grupo sin CL, respectivamente: EVA 4,9 vs. 3,2 ( $p=0,02), 0 D / 34,7$ vs. 23,4 ( $p=0,002)$ y EQ-5D 0,56 vs. 0,75 ( $p=0,01)$. Conclusión: En el presente estudio fue posible observar que la CL está vinculada a peores resultados clínicos después del tratamiento quirúrgico electivo de la columna lumbar.

Descriptores: Columna vertebral/cirugía; Condiciones de trabajo; Calidad de vida; Trabajo; Artrodesis; Fusión vertebral; Psicología social. 


\section{INTRODUCTION}

Low back pain is caused by various nosological entities and modified by external factors and psychosocial causes. Studies show that $50 \%$ to $90 \%$ of adult individuals suffer from low back pain at some point in their lives, causing significant absence from work, surpassing serious pathologies such as cancer, heart attacks, and cerebral vascular accidents, and burdening the social security system. ${ }^{1,2}$ Low back pain is the second most common cause among chronic pathologies for seeking medical care..$^{3,4}$ In developed countries, low back pain is the main cause of disability in individuals under 45 years of age $\mathrm{e}^{3,5}$ and the non-fatal pathology responsible for the most physical constraints worldwide. ${ }^{6}$

The large number of patients with pain in the lumbar spine and the great demand for care have warned medical entities to think about and analyze the patient in other ways, focusing not only on the structural pathology itself, but also on other causes, such as psychological factors, external factors, and secondary gain, that can affect, influence, or worsen an already existing condition and even affect the surgical outcome..$^{7,8}$ In the case of spinal surgery, where the unquestionable presence of organic pathology is a prerequisite for surgery, an evaluation of psychosocial issues is usually neglected, although the medical community today has information about the influence of these issues on the pathological situation. ${ }^{7,9-14}$

International studies show that worker compensation (WC) can be correlated with a negative prognosis following surgical treatment for several orthopedic pathologies, including those of the spine. ${ }^{15-19}$ A Brazilian study ${ }^{14}$ reported postoperative WC results to be lower following spine surgery, but it did not analyze whether the presence of WC prior to surgery was related to different outcomes. The objective of this study was to evaluate the association of clinical results with the preoperative WC situation in patients who underwent spine surgery.

\section{METHODS}

This was a retrospective, single center, comparative study that analyzed the clinical records of patients who had undergone spine surgery. Clinical charts from 2011 to 2016 were analyzed, with exemption from the informed consent form (ICF) according to the approval by the Institutional Review Board (70905017.4.0000.5455). The following cases were included in the study: patients who had undergone elective lumbar spine arthrodesis at a maximum of three levels; patients whose clinical and demographic data was collected in the preoperative period and, at a minimum, at 6 months following surgery; and patients who had completed the Visual Analog Scale (VAS) for pain, the Oswestry Disability Index (ODI) for physical limitation, and the Euroqol 5D (EQ-5D) for quality of life clinical questionnaires.

The following demographic and clinical history data were collected: sex, age at the time of surgery, presence or absence of worker compensation (WC, defined by temporary or permanent paid leave), quantification of the level of depression by the Hospital Anxiety and Depression Scale (HAD-D) questionnaire, quantification of the level of pain by the VAS questionnaire, quantification of physical limitation by the ODI questionnaire, and quantification of the quality of life by the EQ-5D questionnaire.

The patients were divided into two groups: with or without WC in the preoperative period. The two groups were compared both in terms of preoperative presentation and surgical outcome as assessed in the clinical questionnaires between six and 12 months after the intervention.

Descriptive and comparative statistical analyses between the groups were used. The minimal clinically important difference (MCID) was used to assess clinical relevance in the statistical improvement of the pain, physical limitation, and quality of life scores. As previously described, standard MCID values were used. Statistical analyses were performed with the Student's t test and the chi-square test with Pearson's correlation, using an alpha value of 0.05 .

\section{RESULTS}

A total of 132 cases met the inclusion/exclusion criteria and could be analyzed in this study. The data of the study group are shown in Table 1. The group had an average age of 54 years and $51 \%$ of the members were female. Of the 132 cases, 29 patients (22\%) had work compensation (WC). The division by WC into two groups created matched cohorts for the following parameters: average age (54 vs. 54 years of age, $p=0.966)$, sex ( $52 \%$ vs. $45 \%$ female, $p=0.469$, and average level of depression (4.7 vs. 4.6, $p=0.544$ ).

The preoperative clinical presentation of the groups was the same in terms of pain (Figure 1) and physical limitation. (Figure 2) However, quality of life, evaluated by the EQ-5D questionnaire, (Figure 3) presented lower scores (with borderline statistical significance, $p=0.05$ ) for the group with CT as compared to the control group.

The surgical results assessed in the medium term (from 6 to 12 months) showed clinical benefit $(p<0.05)$ in both groups (with and without WC) in all clinical dimensions (pain shown in Figure 1, physical limitation in Figure 2, and quality of life shown in Figure 3). In addition to the statistical significance between the arithmetic averages of the three scales, we observed that both the WC group and the non-WC group exceeded the minimal clinically important difference values (MCID, represented as shaded bars in Figures 1, 2 and 3) for pain, physical limitation, and quality of life.

However, even though both groups benefited from surgery, we confirmed that the WC group had lower postoperative clinical results than the group without WC. The group without WC had an average pain score of 3.2, while the WC group had scored an average of $4.9(p=0.02$, Figure 1). In terms of physical limitation, the group without WC had an average score of 35 points, while the WC group averaged 23 points ( $p=0.01$, Figure 2). On the quality of life scale, the WC group scored 0.75 points and the group without WC scored 0.59 points after surgery ( $p=0.002$, Figure 3$)$.

Table 1. Characteristics of the group studied.

\begin{tabular}{c|c|c|c|c}
\hline & Total & With WC & Without WC & p-value \\
\hline Cases $(n)$ & 132 & $103(78 \%)$ & $29(22 \%)$ & \\
\hline Age (years) & $54 \pm 16$ & $54 \pm 15$ & $54 \pm 17$ & 0.966 \\
\hline Sex $(n ; \%)$ & & & & \\
\hline Female & $67(51 \%)$ & $54(52 \%)$ & $13(45 \%)$ & \multirow{2}{*}{0.469} \\
\hline Male & $65(49 \%)$ & $49(48 \%)$ & $16(55 \%)$ & \\
\hline HAD-D & $4.7 \pm 4.1$ & $4.6 \pm 4.0$ & $5.1 \pm 4.3$ & 0.544 \\
\hline
\end{tabular}

$\mathrm{WC}=$ worker compensation; HAD-D = depression score from the Hospital Anxiety and Depression scale questionnaire.

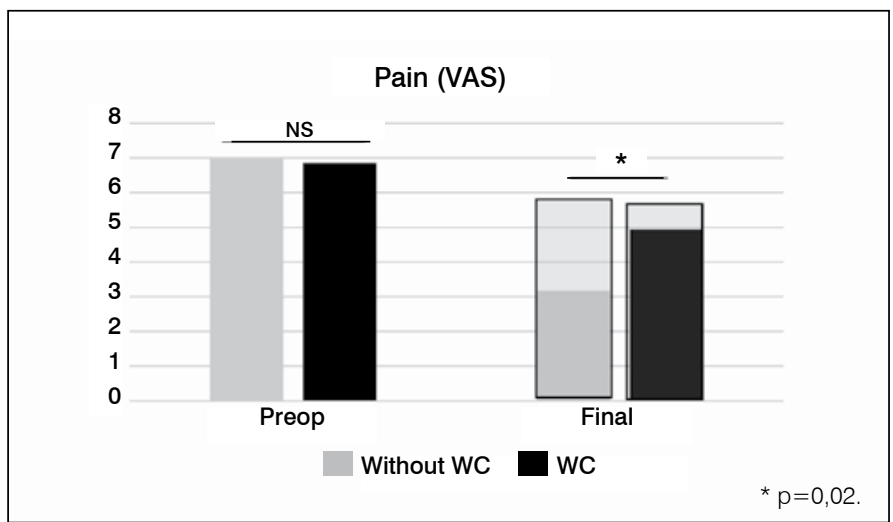

Figure 1. Pain scores (VAS questionnaire) in patients without and with WC (worker compensation), in the preoperative (Preop) and final periods. Shaded bars in the Final period represent the value of the minimal clinically important difference (MCID). The two groups show improvement from the Preop period to the Final period. NS - non-significant $(p=0.834)$. 


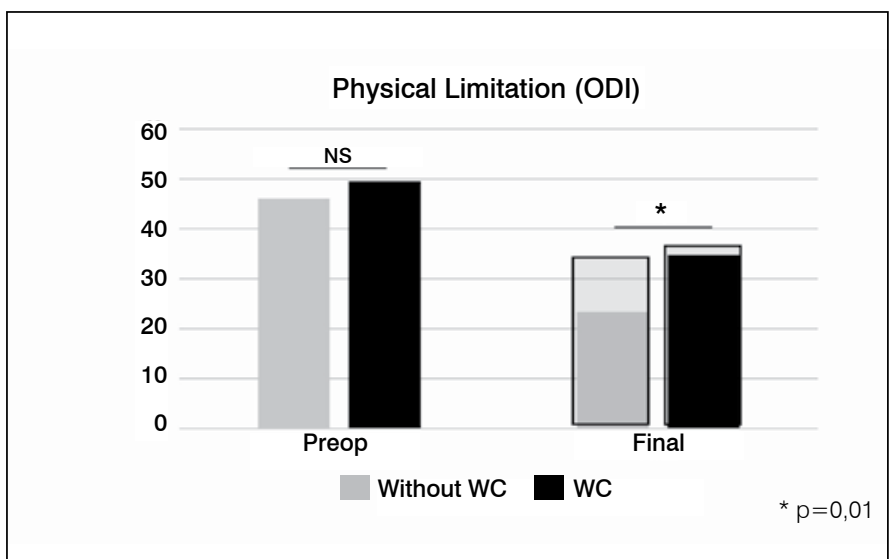

Figure 2. Physical limitation scores (ODI questionnaire) in patients without or with WC (worker compensation) in the preoperative (Preop) and final periods. Shaded bars in the Final period represent the value of the minimal clinically important difference (MCID). The two groups show improvement from the Preop period to the Final period. NS - non-significant $(p=0.295)$.

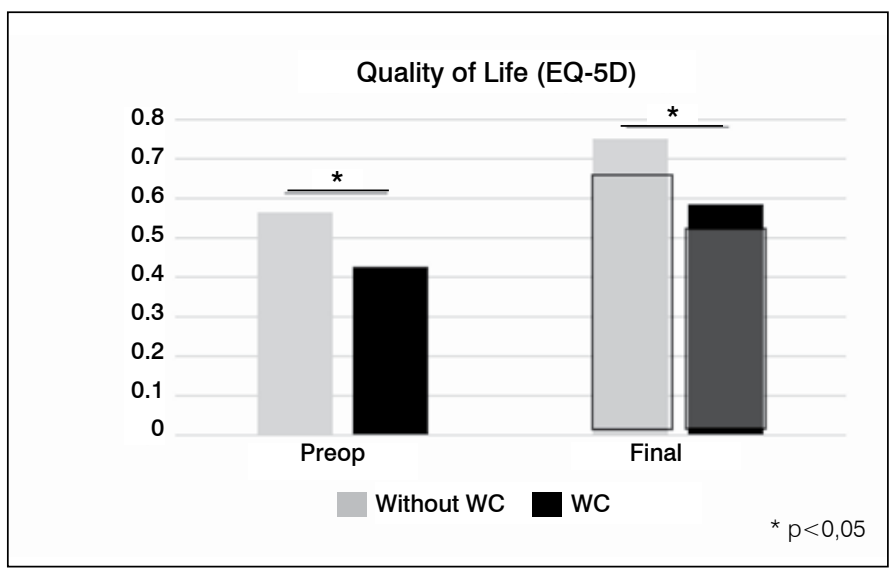

Figure 3. Quality of life scores (EQ-5D questionnaire) in patients without or with WC (worker compensation) in the preoperative (Preop) and final periods. Shaded bars in the Final period represent the value of the minimal clinically important difference (MCID). The two groups show improvement from the Preop period to the Final period.

\section{DISCUSSION}

Today, the influence of psychological and social factors on pain profiles and on spine surgery outcomes has is highlighted. One of the most important factors in this area is worker compensation (WC). In this study we analyzed the clinical outcomes of patients who had undergone elective lumbar interbody arthrodesis, separating them into two groups: patients with and without WC. We observed differences between the surgical results, with the presence of WC being associated with worse pain, physical limitation, and quality of life scores.

Nowadays, it is understood that the clinical presentation of pain profiles, such as those stemming from spinal problems, should be analyzed in conjunction with factors beyond just the pathophysiological findings. ${ }^{20-22}$ Large centers and various authors have reported that social and psychological disorders, such as anxiety, depression, hopelessness, sensitivity to stress, sexual disorders, sleep disorders, marital problems, litigation, and worker compensation occur more frequently in patients with spinal problems. ${ }^{1,3,8,12,23-28}$ And even more importantly, some of these factors can negatively impact surgical treatment of the spine, depression being a factor frequently studied in the psychological field ${ }^{23,25}$ and WC the most often cited factor in the social arena. ${ }^{7,29-31}$
In 2015, a systematic review and meta-analysis ${ }^{7}$ of the literature contained in the MEDLINE, EMBASE, Cochrane Collaboration Library, Scopus, and Google Scholar data bases was conducted. Thirty-one studies that evaluated the effect of WC on spine surgery were included. Of these studies, 26 were conducted in the USA, four in the United Kingdom, two in Australia, and one in Switzerland. It should be noted here that no published Brazilian study was found in these repositories at that time. In this study, it was confirmed that the group with WC tends to stay away from work activities following surgery $(57.4 \%$ return for the WC group and $82.9 \%$ for the non-WC group). Non-satisfactory clinical outcomes were more prevalent in the WC group, with a relative risk of $2.12([1.74,2.58], p<0.001)$. The findings of the studies in the USA were similar to the European and Australian data. ${ }^{7}$ The relative risk was 2 , similar to that one found in the results of the meta-analysis ${ }^{32}$ of orthopedic surgeries of the upper limbs.

A 2015 Brazilian study ${ }^{14}$ analyzed 111 patients who had undergone surgery for degenerative spine disease. The clinical outcomes were extracted from the SF-36 questionnaire. For comparison, the patients were divided according to their work situation one year after surgery. Here we highlight the difference between the analyses conducted by those authors and in our study: they analyzed the results one year following surgery of patients who continued or were granted a leave from work and our study analyzed the influence of WC prior to surgery on the postoperative outcome. The authors of the study observed that the two groups of patients benefited from surgery, but the group that returned to work activities had better scores on questions in the functional, physical, pain, vitality, social, and mental categories.

The link between worse outcomes and the presence of WC is still not yet fully understood, but the situation is complex in that external factors can be directly tied to said compensation and thus negatively influence outcomes. The higher risks of physical injury in more strenuous jobs, secondary social gains, a lower educational level, and the presence of prior surgeries can be cited as confounding factors. In addition to the items directly tied to WC, it has already been proven that other items can have a cumulative effect with WC: the prolonged use of opioids, lawsuits, and depression, the later being that with the greatest cumulative impact. ${ }^{25,29,33}$ Identifying WC and other related factors can be of great value to the surgeon in light of the data presented in the literature. Thus, it is important to understand this phenomenon and encourage surgeons to take compensation status into account, among other psychosocial issues, to weigh treatment expectations.

Despite being a pioneer study on the topic in Brazil, this study has limitations that can be pointed out and overcome in future analyses: the single center experience, the limited number of patients, and the need for multivariate analysis that takes other factors recognized as having influence on outcomes into account.

\section{CONCLUSIONS}

In addition to objective questions related to the physiopathology of spinal conditions, other psychological or social factors may be linked to different clinical presentations or even to the results obtained following surgical treatment. In this study, we observed that the work situation of the individual submitted to elective lumbar surgery is related to different outcomes after treatment. The presence of worker compensation in the preoperative period was related to worse clinical outcomes. The identification of said work situation may be useful in setting the expectations for surgical treatment of both the surgeon and the patient.

All authors declare no potential conflict of interest related to this article. 
CONTRIBUTION OF THE AUTHORS: This manuscript, which is a singled center study, had nine authors. Each author made significant individual contributions to this manuscript. LM and VA were the main contributors to the writing of the manuscript. LP, RA, RJ, NF, LO and EC performed the surgeries, followed-up with patients, and collected clinical data. LM evaluated the statistical analysis data. LM conducted the bibliographical research. LM, LO, VA, JNN, RA, and LP contributed to the intellectual concept of the study. All authors participated actively in the discussion of the results, saw and agree with the version of the manuscript submitted.

\section{REFERENCES}

1. Bigos S, Bowyer O, Braen G, Brown K, Deyo R, Haldeman S, et al. Acute Low Back Problems in Adults. Clinical Practice Guideline No. 14. AHCPR Publication No. 95-0642. Rockville, MD: Agency for Health Care Policy and Research, Public Health Service, U.S. Department of Health and Human Services; 1994.

2. Baumeister $H$, Knecht $A$, Hutter N. Direct and indirect costs in persons with chronic back pain and comorbid mental disorders--a systematic review. J Psychosom Res. 2012;73(2):79-85.

3. Andersson GB. Epidemiology of spinal disorders. In: Frymoyer JW, Ducker TB, editors. The adult spine: principles and practice. New York: Raven Press; 1991. p. 93-141.

4. Addison R, Schultz A. Trunk strengths in patients seeking hospitalization for chronic lowback disorders. Spine (Phila Pa 1976). 1980;5(6):539-44.

5. Andersson GBJ. Epidemiology. In: Weinstein JN, Rydevik BL, Sonntag VKH, editors. Essentials of the spine. New York: Raven Press; 1995. p. 1-10.

6. Vos T, Flaxman AD, Naghavi M, Lozano R, Michaud C, Ezzati M, et al. Years lived with disability (YLDs) for 1160 sequelae of 289 diseases and injuries 1990-2010: a systematic analysis for the Global Burden of Disease Study 2010. Lancet. 2012:380(9859):2163-96.

7. Cheriyan T, Harris B, Cheriyan J, Lafage V, Spivak JM, Bendo JA, et al. Association between compensation status and outcomes in spine surgery: a meta-analysis of 31 studies. Spine J. 2015;15(12):2564-73.

8. Moore JE. Chronic low back pain and psychosocial issues. Phys Med Rehabil Clin N Am. 2010;21(4):801-15

9. Teixeira MJ. Dor e depressão. Rev Neurocienc. 2006;14(2):44-53.

10. Falavigna A, Righesso NO, Teles AR. Avaliação clínica e funcional no pré-operatório de doenças degenerativas da coluna vertebral. Coluna/Columna. 2009;8(3):245-53.

11. Amaral $V$, Marchi $L$, Oliveira $L$, Pimenta $L$. Prevalência e relação de fatores emocionais e clínicos em pacientes com discopatia degenerativa. Coluna/Columna. 2010:9(2):150-6

12. Trief PM, Grant W, Fredrickson B. A prospective study of psychological predictors of lumbar surgery outcome. Spine (Phila Pa 1976). 2000;25(20):2616-21.

13. Adogwa O, Carr K, Fatemi P, Verla T, Gazcon G, Gottfried O, et al. Psychosocial factors and surgical outcomes: are elderly depressed patients less satisfied with surgery? Spine (Phila Pa 1976). 2014;39(19):1614-9

14. Motter BV, Machado AN, Brandão TK, Ueno FH, Cesar AEM, Rodrigues LMR. Quality of life in patients before and after lumbar surgery in different work situations. Coluna/ Columna. 2015;14(3):198-201.

15. Holtby R, Razmjou H. Impact of work-related compensation claims on surgical outcome of patients with rotator cuff related pathologies: a matched case-control study. J Shoulder Elbow Surg. 2010;19(3):452-60.

16. Anderson PA, Subach BR, Riew KD. Predictors of outcome after anterior cervical discectomy and fusion: a multivariate analysis. Spine (Phila Pa 1976). 2009;34(2):161-6.

17. Hou WH, Tsauo JY, Lin CH, Liang HW, Du CL. Worker's compensation and return-to-work following orthopaedic injury to extremities. J Rehabil Med. 2008;40(6):440-5.

18. Bhatia S, Piasecki DP, Nho SJ, Romeo AA, Cole BJ, Nicholson GP, et al. Early return to work in workers' compensation patients after arthroscopic full-thickness rotator cuff repair. Arthroscopy. 2010;26(8):1027-34.

19. Denard PJ Lädermann A, Burkhart SS, Long-term outcome after arthroscopic repair of type II SLAP lesions: results according to age and workers' compensation status. Arthroscopy. 2012;28(4):451-7.

20. Falavigna A, Teles AR, Braga GL, Barazzetti DO, Lazzaretti L, Tregnago AC. Instrumentos de avaliação clínica e funcional em cirurgia da coluna vertebral. Coluna/Columna. 2011;10(1):62-7.

21. Mannion AF, Elfering A. Predictors of surgical outcome and their assessment. Eur Spine J. 2006;15 Suppl 1:S93-108.

22. Li S, Qi M, Yuan W, Chen $H$. The impact of the depression and anxiety on prognosis of cervical total disc replacement. Spine (Phila Pa 1976). 2015;40(5):E266-71.

23. Adogwa O, Parker SL, Shau DN, Mendenhall SK, Aaronson OS, Cheng JS, et al. Preoperative Zung Depression Scale predicts outcome after revision lumbar surgery for adjacent segment disease, recurrent stenosis, and pseudarthrosis. Spine J. 2012;12(3):179-85.

24. Anderson JT, Haas AR, Percy R, Woods ST, Ahn UM, Ahn NU. Clinical depression is a strong predictor of poor lumbar fusion outcomes among workers' compensation subjects. Spine (Phila Pa 1976). 2015;40(10):748-56.

25. Theologis AA, Ailon T, Scheer JK, Smith JS, Shaffrey Cl, Bess S, et al. Impact of preoperative depression on 2-year clinical outcomes following adult spinal deformity surgery: the importance of risk stratification based on type of psychological distress. J Neurosurg Spine. 2016;25(4):477-485.

26. Linton SJ. A review of psychological risk factors in back and neck pain. Spine (Phila Pa 1976). 2000;25(9):1148-56

27. Magnusson $M$, Granqvist $M$, Jonson $R$, Lindell $V$, Lundberg $U$, Wallin $L$, et al. The loads on the lumbar spine during work at an assembly line. The risks for fatigue injuries of vertebral bodies. Spine (Phila Pa 1976). 1990;15(8):774-9

28. Anderson JT, Haas AR, Percy R, Woods ST, Ahn UM, Ahn NU. Workers' Compensation, Return to Work, and Lumbar Fusion for Spondylolisthesis. Orthopedics. 2016;39(1):e1-8.

29. Pelton MA, Phillips FM, Singh K. A comparison of perioperative costs and outcomes in patients with and without workers' compensation claims treated with minimally invasive or open transforaminal lumbar interbody fusion. Spine (Phila Pa 1976) 2012:37(22):1914-9.

30. Turner JA, Franklin G, Fulton-Kehoe D, Sheppard L, Wickizer TM, Wu R, et al. Worker recovery expectations and fear-avoidance predict work disability in a population-based workers' compensation back pain sample. Spine (Phila Pa 1976). 2006;31(6):682-9.

31. de Moraes VY, Godin K, Tamaoki MJ, Faloppa F, Bhandari M, Belloti JC. Workers' compensation status: does it affect orthopaedic surgery outcomes? A meta-analysis. PLOS One. 2012;7(12):e50251.

32. DeBerard MS, LaCaille RA, Spielmans G, Colledge A, Parlin MA. Outcomes and presurgery correlates of lumbar discectomy in Utah Workers' Compensation patients. Spine J. 2009;9(3):193-203 